\title{
Retail Sector in India: Present Scenario, Emerging Opportunities and Challenges
}

\author{
Prof. Kalpana Singh \\ (Amity School of Economics/ Amity University, Noida, U.P., India)
}

\begin{abstract}
The Government's initiative to allow 51 per cent foreign direct investment (FDI) in multi-brand retail has been a subject for debate for quite some time now. Indian retail sector has therefore attracted the attention of people from various fields including academia, industry, research organisations. The present study is undertaken to gain an insight about the present structure of Indian Retail Sector, the major sub-sectors in organized and traditional retail and changes in the relative share of various sub-sectors over last few years and penetration of organized retail in various segments. The analysis also covers the opportunities and emerging challenges before Indian retail sector in view of recent policy changes by Government of India. With India's large 'young' population and high domestic consumption, the macro trends for the sector look favorable. The Indian retail sector is highly fragmented with more than ninety per cent of its business being run by the unorganized retailers like the traditional family run stores and corner stores. During 2005-07 and 2007-10, the share of organized retail increased by 13.9 percent and 21.9 percent respectively. However thereafter organized retail is penetrating the market at a more rapid pace. During the period 2010-12 share of organized retail rose by 60 percent and is expected to increase by 2.6 times during 2012-15. Clothing/Apparel segment is the biggest contributor in organised retailing in India in both the years of study. In 2012 it alone accounted for 33 percent of organized retail followed by Food \& Grocery and Mobile and telecom with each having 11 percent share in organized retail. Organized retail had highest penetration in Apparel both in 2007 and 2012. Food and Grocery segment is dominated by traditional retail but in 2012, organized retail penetration in this sector had more than doubled. In view of the recent policy changes, both the existing traditional retailers and modern organised domestic and foreign retailers would have opportunities and face challenges. On one hand, the policy exposes the domestic retailers to competition from foreign retailers; while on the other hand, it seeks to safeguard them through a slew of protective measures. The future prospects of Indian retail market are likely to have some macro-economic impact too. Prospective reduction in supply chain impediments may help in reducing supply side inflationary pressures. Future growth of India's retail sector is also expected to increase employment. The nuances of FDI in retail are still to be worked out.
\end{abstract}

Keywords: challenges and Emerging opportunities, Market Penetration, Organised, Retail Sector, Traditional

\section{Introduction}

The word 'retail' means the sale of goods or commodities in small quantities directly to consumers Retailing can be defined as a distribution channel function, where an organization, buying the products from supplying firms or manufacturing the products themselves, sells these directly to consumers. Many a times, consumers buy from an organization who is not the manufacturer of the products, rather it is a reseller of the products obtained from others. However, in some cases we may find the product manufacturers operating their own retail outlets in a corporate channel arrangement. Retailing is beneficial to both consumers and sellers. On the one hand it enables the consumers to purchase small quantities of an assortment of products at a reasonably affordable price, on the other it offers an opportunity to suppliers to reach their target market. Through retail promotions they can build product demand and provide consumer feedback to the product marketer [1]. Thus retail consists of sale of goods and services from individuals or businesses to the end-user. A retailer earns profit by purchasing large quantities of goods and services either from manufacturers directly or through a wholesale and he is a part of an integrated system called the supply chain [2].

The size of Indian retail market in 2010 was estimated at US\$ 353 billion and by 2014, it is expected to increase up to US\$ 543 billion [3].Further, the estimated value of current size of Indian retail market is about 500 billion USD and by 2020 its value is pegged to be at 1.3 trillion USD. Over 20 per cent of India's gross domestic product (GDP) is contributed by retail sector and in total employment it contributes eight percent [4]. India is Home to one of the top five retail markets in the world and in retail, India offers immense scope of growth and opportunities [5]. According to A T Kearney's Global Retail Development Index (GRDI) 2013, the global slowdown has impacted India's growth also and as a result India's growth rate fell from a 10-year average of 7.8 percent to 5 percent and in GRDI ranking India slipped to 14th. India's previous low ranking was 6th place in the inaugural Index in 2002 but in 2009 it stood first. However the GRDI report points out some positive factors leading to optimistic expectations. These factors are: strong long-term fundamentals and young, 
increasingly brand-and fashion-conscious population. The report projects 14 to 15 percent growth per year in retail sector through 2015 and due to more urbanization and more potential new investment by retailers, expects a higher proportion of modern retail which is 7 percent in 2012[6].

In 'Sector profile' of Indian retail sector, FICCI (2011) also projects an optimistic future. An important contributory factor in growth of India's retail sector is growing middle class which is expected to increase from 21 million households today to 91 million households in 2030.It expects, 570 million people to live in cities in 2030, which is nearly twice the population of the United States today. High and growing domestic consumption is another factor expected to contribute in potential growth of India's retail sector. India's modern consumption level which presently is US\$ 750 billion may double within five years to US\$ 1.5 trillion [7]. Thus, India's huge population with large proportion of 'young' population, high potential growth in consumer expenditure, the macro trends for the sector look favorable.

Optimism about high potential of growth in organized retail in India has also been shown by Equitymaster [3]. The views expressed here indicate that in past, a large part of India's consumption needs was accounted by food but now transition is taking place from traditional retail to organised retailing due to changing consumer expectations, demographic mix, etc. The new generation appreciates mall culture which makes it convenient to shop with multiplicity of choice under one roof (Shop- in Shop). Over the long run, these are expected to be the growth drivers of organised retailing in India. Further, FICCI states that despite the downturns, , the organized retail market in India is growing exponentially due to growing consuming classes resulting from economic growth and organized retail is attracting more and more existing shoppers into its open doors[7]. By 2015, organised retail segment is estimated to grow (at a rate of almost 30\%,) at a much faster pace than the overall retail market which is forecast to grow by $16 \%$ in the same period [8]. The Government's initiative to allow 51 per cent foreign direct investment (FDI) in multi-brand retail has been a subject for debate for quite some time now. Indian retail sector has therefore attracted the attention of people from various fields including academia, industry, research organisations etc.

\subsection{Literature Review}

Several studies have been undertaken in the field of retail sector in India. Besides, one may also find articles in newspapers, business magazines relating to retail sector in India. Few of them are mentioned here. Subhadip Mukherjee's study examines the government policies of different countries including India in respect of unorganized and organized retail sector [9]. The study examines whether, for the small and unorganized retailers to sustain in this big fight the government provides a tight legal framework along with economic support. The study finds that small as well as big domestic retail chains had been helped by the governments of different countries (including India) through formulating appropriate policies over time, by providing capital support and/or formulating strict legislations to restrict entry of foreign retailers in their respective countries. In India, all the regulations regarding retail sector varies across states and their impacts are also heterogeneous since these regulations are still in state level and are being influenced by the existing political parties of different states.

An article in Business Standard, summarises the findings of India Ratings regarding future prospects of Indian retail sector [10]. These findings presents a 'negative outlook' for the retail sector and expects luxury segment to be the worst hit in 2013. According to the Report, for the first time in the history, in 2012, the retail sector registered a single digit growth, and overall revenue is likely to grow at 3-8\% year-on-year across large retailer. According to the report, the major factor accounting for sales growth in 2012 was discount offers by companies and the trend is likely to continue in 2013.The agency expects that a sustained reduction in consumer price inflation, coupled with rise in wages may restore the discretionary spending of power of consumers and liberalisation of FDI in multi-brand retail could have a positive impact on the retail sector.

A report published by Corporate Catalyst India, focuses on segment analysis of Indian retail market, Key players and profiles of Key players, business models for entry in Indian markets and opportunities and challenges in retailing [11]. Expressing experts' opinion, the report states that in future, the retail industry in India will be a major employment generator. It further says that the market share of organised modern retail being just over 4 per cent of the total retail industry in 2009, it leaves a huge untapped opportunity. Fashion retailing, which commands a large chunk of the organised retail business in India, has indeed been responsible for single handedly driving the business of retail in India.

A report titled 'Indian Retail Industry: Challenges, Opportunities and Outlook'(2009), published by Dun \& Bradstreet, the world's leading source of global business information, describes the Global Retail Scenario, Evolution of organised retail, Size of the Indian retail industry, Industry segmentation, and Regulatory Framework [1].

Deloitte, a business specialist and consulting firm has also published some reports containing several aspects relating to retail sector in India. The report titled "Indian Retail Market Embracing a new trajectory", 2011 covers issues- the size and trends in retail sector, FDI into retail, market opportunities, tax 
and regulatory structure, sector analysis etc [12]. The report states that although all the retail segments offer growth opportunities for foreign retailers, the largest opportunity in terms of potential market size and scalability is in grocery retailing, particularly for the supermarket and hypermarket formats. However, the large population of 'mom-n-pop'/'kirana' grocery stores is likely to be a force to reckon with for new foreign entrants.

An another report published by Delloite titled "Indian Retail Market Opening more doors" (2013) is mainly focused on government policy on multi-brand retail trade-its evolution, policy implications and political landscape with respect to new FDI policy[13]. The report states that various policy conditions for FDI in multibrand retail makes mass grocery and apparel the two most favorable segments. Multi-brand specialty retail segment such as Beauty \& Wellness and Consumer Electronics are still in their nascent stage. Their current market size may not hold a big potential for foreign retailers.

Research article titled "Sector Profile", gives a brief description of current status of the retail sector, its future scope and challenges faced by the sector [7].

PricewaterhouseCoopers (a multinational professional services firm), India's report, "Winning-inIndia's-retail-sector, Factors for success", 2011, focuses on the main drivers, trends and issues in India's retail sector [14]. It also presents an overview of the key tax and regulatory issues, a discussion on the benefits of modern trade, factors for succeeding in the Indian market. The report states that large size of Indian retail market, low organised retail penetration, strong GDP growth, increasing personal incomes, large number of aspirational consumers (middle-class, young Indians, rural population, etc.) make India an exciting and dynamic retail destination. It further states that the Indian retail market is evolving rapidly, becoming more competitive and retailers understand the importance of meeting consumer demands. In such a competitive environment, the main driver of competitive advantage will be supply chain mastery. The use of supply chain and logistics will make retailers agile and cost-competitive in a more crowded retail sector. ASA and Associates' (2012) report titled "A Brief Report on Retail Sector in India", gives an overview of India's retail sector, growth in retail sector. It also describes government policy with respect to retail sector and major global players in Indian retail [15].

\subsection{Objectives}

1) To analyse the present structure of Indian Retail Sector and changes therein during last few years.

2) To make a segment analysis of Indian Retail Sector in order to know about the major sub-sectors in organized and traditional retail and changes in the relative share of various sub-sectors over last few years and penetration of organized retail in various segments.

3) To understand and analyse the emerging challenges before Indian retail sector in view of recent policy changes by Government of India.

4) To find out some measures/steps need to be taken by Indian retailers to meet successfully the emerging global competition in the sector.

\subsection{Methodology}

The present study is based on secondary data and information collected from a variety of sources. An attempt has been made in the present study to make a systematic analysis of changes in the size and structure of Indian retail market over last few years. This analysis is useful to understand the expected future changes in the Indian retail market and the implications of recent policy changes adopted by Government of India. Collecting and compiling data and information from various available sources, relevant ratios and percentages have been calculated and analysed.

\subsection{Organised and Unorganised (Traditional) Retail}

The total retail sector in India can be divided into organized and unorganised sectors. The trading activities undertaken by licensed retailers are categorized as organized retailing. Licensed retailers are those who are registered for sales tax, income tax, etc. These include the corporate-backed hypermarkets and retail chains, and also the privately owned large retail businesses. Unorganized retail or traditional retail on the other hand, include a large number of small retailers that consists of local kirana shops, owner-manned general stores, chemists, footwear shops, apparel shops, paan and beedi (local betel leaf and tobacco) shops, hand-cart hawkers, pavement vendors, etc [16].

Retailing is one of the most prominent industries in developed markets whereas in developing economies the concept had occurred much later. The contribution of US retail sector to the GDP was $31 \%$ at current market prices in 2008. In developed economies, organised retail has a 75-80\% share in total retail while in developing economies; it is the un-organised retail that has a dominant share [1]. The figures regarding relative shares of organized and traditional retail in total retail for few countries are presented in Table 1. 
As shown in the Table, the share of organized retail is very high in US ( 85 percent). In Taiwan also it is more than eighty percent. India is far behind so far as organized retail is concerned. In India the share of organized retail is currently eight percent [13].

Table 1: Relative Share of Organized and Traditional retail in Selected Countries, 2009

\begin{tabular}{|l|l|l|l|l|}
\hline S. No. & Country & $\begin{array}{l}\text { Total Retail Sales } \\
\text { (US\$ bn) }\end{array}$ & Share of Organized Retail & $\begin{array}{c}\text { Share of Traditional } \\
\text { Retail* }\end{array}$ \\
\hline 01. & USA & 2983 & 85 & 15 \\
\hline 02. & Japan & 1182 & 66 & 34 \\
\hline 03. & China & 785 & 20 & 80 \\
\hline 04. & United Kingdom & 475 & 80 & 20 \\
\hline 05. & France & 436 & 80 & 20 \\
\hline 06. & Germany & 421 & 80 & 20 \\
\hline 07. & India & 322 & 4 & 96 \\
\hline 08. & Brazil & 284 & 36 & 64 \\
\hline 09. & Russia & 276 & 33 & 67 \\
\hline 10. & Korea (South) & 201 & 15 & 85 \\
\hline 11. & Indonesia & 150 & 30 & 70 \\
\hline 12. & Poland & 120 & 20 & 80 \\
\hline 13. & Thailand & 68 & 40 & 60 \\
\hline 14. & Pakistan & 67 & 1 & 99 \\
\hline 15. & Argentina & 53 & 40 & 60 \\
\hline 16. & Philippines & 51 & 35 & 65 \\
\hline 17. & Malaysia & 34 & 55 & 45 \\
\hline 18. & Czech Republic & 34 & 30 & 70 \\
\hline 19. & Vietnam & 26 & 22 & 78 \\
\hline 20. & Hungary & 24 & 30 & 70 \\
\hline
\end{tabular}

Source: Girish K. Nair and Harish K Nair (2011), "FDI in India's Multi Brand Retail Sector": How to Get Ready for the Big Play”, Munich, GRIN Publishing [17].

* Author's Calculations

The Indian retail sector is highly fragmented. More than ninety per cent of its business is being run by the unorganized retailers like the traditional family run stores and corner stores. The organized retail in India is at a very nascent stage. However, in order to increase its share in total retail, attempts are being made so as to bring in a huge opportunity for prospective new players. India's retail sector is heading towards modernization. New formats such as departmental stores, supermarkets and speciality stores, Westernised malls are fast appearing in metros and tier-II cities [16]. Table 2 presents the figures for relative shares of organized and traditional retail in Indian retail market.

Table 2: Indian Retail Market (Organized \& Traditional) percentage share

\begin{tabular}{|l|l|l|}
\hline Year & Organized & Traditional \\
\hline 2005 & 3.6 & 96.4 \\
\hline 2007 & 4.1 & 95.9 \\
\hline 2010 & 5.0 & 95.0 \\
\hline 2012 & 8.0 & 92.0 \\
\hline $2015^{\mathrm{E}}$ & 21.0 & 79.0 \\
\hline $2020^{\mathrm{E}}$ & 24.0 & 76.0 \\
\hline
\end{tabular}

E - Expected

\section{Source:}

1. Deloitte (2011)," Indian Retail Market: Embracing a new trajectory”, September, [12] (For 2005 and 2015)

2. FICCI(2011), "Sector Profile",2 December,[7]_(For 2010 and 2020)

3. Deloitte (2013), "Indian Retail Market Opening more doors", January,[13] (For 2012)

4. ASA(2012), "A Brief Report on Retail Sector in India", August, ASA and Associates chartered accountants, [15] (For 2007) 


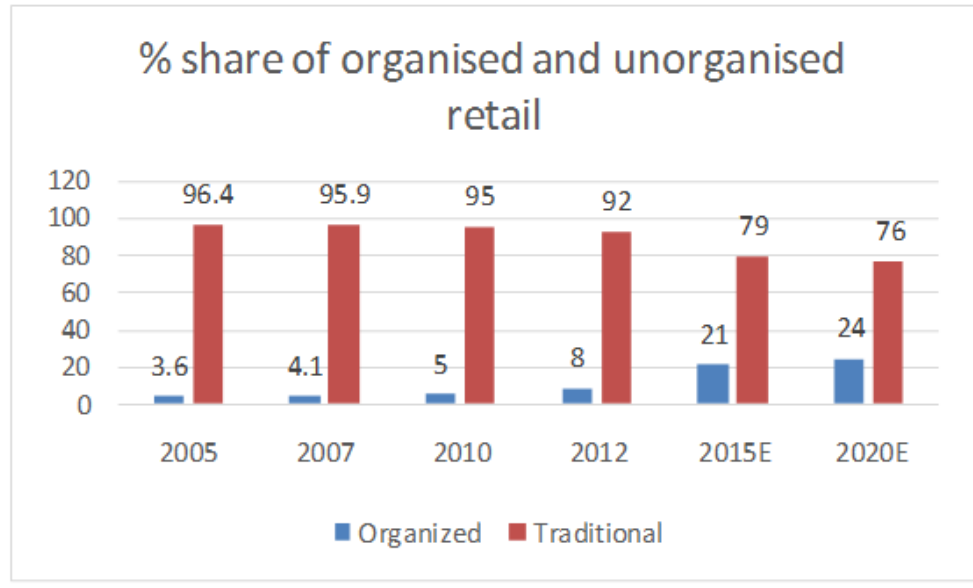

Source: Author's Compilation

Figure 1

The Table 2 reflects that during the periods 2005-07 and 2007-10, the increase in share of organized retail was not much. During these periods it increased by 13.9 percent and 21.9 percent respectively. However thereafter organized retail is penetrating the market at a more rapid pace. During the period 2010-12 share of organized retail rose by 60 percent, its share in total retail had just doubled and is expected to increase by 2.6 times during 2012-15. As mentioned in FICCI (2011), over the next 10 years India's retail market is expected to grow at $7 \%$ and by 2020 it is expected to reach a size of US\$ 850 billion. The expected growth in traditional retail is estimated to be at $5 \%$ while organized retail is expected to grow at $25 \%$.The traditional and organized retail are expected to reach a size of US\$ 650 billion(76\% of total) and US\$200 (24\% of total)billion respectively by $2020[7]$.

\subsection{Segment Analysis}

Tables 3 and 4 gives an account of the relative contribution of various segments in Indian retail market along with the Penetration of organized retail in years 2007 and 2012 respectively.

Table 3: Total, Organised and Traditional Retail Market in India (2007)

\begin{tabular}{|c|c|c|c|c|c|c|}
\hline $\begin{array}{l}\text { Sl. } \\
\text { No. }\end{array}$ & Segments & $\begin{array}{l}\text { Total Retail } \\
\text { Market } \\
\text { (Rs Billion) }\end{array}$ & $\begin{array}{l}\text { Organised } \\
\text { Retail } \\
\text { Market (Rs } \\
\text { Billion) } \\
\end{array}$ & $\begin{array}{l}\text { Traditional } \\
\text { Retail } \\
\text { Market (Rs } \\
\text { Billion) } \\
\end{array}$ & $\begin{array}{l}\text { Penetration } \\
\text { of organised } \\
\text { Retail }(\%)\end{array}$ & $\begin{array}{l}\text { Penetration } \\
\text { of } \\
\text { Traditional } \\
\text { Retail (\%) }\end{array}$ \\
\hline (1) & (2) & (3) & (4) & (5) & (6) & (7) \\
\hline 1 & Food \& grocery & $\begin{array}{l}8,680 \\
(\mathbf{5 9 . 5 6 )}\end{array}$ & $\begin{array}{l}61 \\
(\mathbf{1 0 . 2})\end{array}$ & $\begin{array}{l}8,619 \\
(61.7)\end{array}$ & 0.70 & 99.30 \\
\hline 2 & Bewerages & $\begin{array}{l}518 \\
(3.55) \\
\end{array}$ & $\begin{array}{l}16 \\
(2.7) \\
\end{array}$ & $\begin{array}{l}502 \\
(3.6) \\
\end{array}$ & 3.09 & 96.91 \\
\hline 3 & Clothing \& Footwear & $\begin{array}{l}1,356 \\
(\mathbf{9 . 3 0})\end{array}$ & $\begin{array}{l}251 \\
(\mathbf{4 2 . 0})\end{array}$ & $\begin{array}{l}1,105 \\
(7.9)\end{array}$ & 18.51 & 81.49 \\
\hline 4 & $\begin{array}{l}\text { Furniture, Furnishing, } \\
\text { Appliance and Services }\end{array}$ & $\begin{array}{l}986 \\
(6.77)\end{array}$ & $\begin{array}{l}101 \\
(16.9)\end{array}$ & $\begin{array}{l}885 \\
(6.3)\end{array}$ & 10.24 & 89.76 \\
\hline 5 & Non Institutional Health care & $\begin{array}{l}1,159 \\
(\mathbf{7 . 9 5})\end{array}$ & $\begin{array}{l}24 \\
(4.0) \\
\end{array}$ & $\begin{array}{l}1,135 \\
(8.1)\end{array}$ & 2.07 & 97.93 \\
\hline 6 & $\begin{array}{l}\text { Sports goods, Entertainment, } \\
\text { Equipment and Books }\end{array}$ & $\begin{array}{l}395 \\
(2.71)\end{array}$ & $\begin{array}{l}63 \\
(\mathbf{1 0 . 5})\end{array}$ & $\begin{array}{l}332 \\
(2.4)\end{array}$ & 15.95 & 84.05 \\
\hline 7 & Personal care & $\begin{array}{l}617 \\
(4.23) \\
\end{array}$ & $\begin{array}{l}33 \\
(5.5) \\
\end{array}$ & $\begin{array}{l}584 \\
(4.2) \\
\end{array}$ & 5.35 & 94.65 \\
\hline 8 & Jewellery, Watches etc & $\begin{array}{l}863 \\
(5.92) \\
\end{array}$ & $\begin{array}{l}49 \\
(8.2)\end{array}$ & $\begin{array}{l}814 \\
(5.8) \\
\end{array}$ & 5.68 & 94.32 \\
\hline 9 & Total retail & 14,574 & 598 & 13,976 & 4.10 & 95.90 \\
\hline
\end{tabular}

Note: Figures in parentheses show the percentage share in total

Source:

1. For columns 2,3 \&4, ASA (2012), "A Brief Report on Retail Sector in India", August, ASA and Associates chartered accountants[15]

2. For columns 5,6 \&7, Author's calculations 
Table 4: Total, Organised and Traditional Retail Market in India (2012)

\begin{tabular}{|c|c|c|c|c|c|c|}
\hline $\begin{array}{l}\text { Sl. } \\
\text { No. }\end{array}$ & Segments & $\begin{array}{l}\text { Total Retail } \\
\text { Market } \\
\text { (USD Billion) }\end{array}$ & $\begin{array}{l}\text { Organised } \\
\text { Retail } \\
\text { Market } \\
\text { (USD } \\
\text { Billion) } \\
\end{array}$ & $\begin{array}{l}\text { Traditional } \\
\text { Retail } \\
\text { Market } \\
\text { (USD } \\
\text { Billion) } \\
\end{array}$ & $\begin{array}{l}\text { Penetration } \\
\text { of organised } \\
\text { Retail }(\%)\end{array}$ & $\begin{array}{l}\text { Penetration } \\
\text { of Traditional } \\
\text { Retail }(\%)\end{array}$ \\
\hline (1) & (2) & (3) & $(4)$ & $(5)$ & (6) & (7) \\
\hline 1 & Food and Grocery & $\begin{array}{l}310.8 \\
(\mathbf{6 0 . 0})\end{array}$ & $\begin{array}{l}4.56 \\
(11.0)\end{array}$ & $\begin{array}{l}306.24 \\
(64.0) \\
\end{array}$ & 1.5 & 98.5 \\
\hline 2 & Apparel & $\begin{array}{l}41.44 \\
(\mathbf{8 . 0})\end{array}$ & $\begin{array}{l}13.68 \\
(33.0) \\
\end{array}$ & $\begin{array}{l}27.76 \\
(6.0)\end{array}$ & 33.0 & 67.0 \\
\hline 3 & Mobile and telecom & $\begin{array}{l}31.08 \\
(6.0) \\
\end{array}$ & $\begin{array}{l}4.56 \\
(11.0) \\
\end{array}$ & $\begin{array}{l}26.52 \\
(6.0)\end{array}$ & 14.7 & 85.3 \\
\hline 4 & Jewellery & $\begin{array}{l}20.72 \\
(4.0) \\
\end{array}$ & $\begin{array}{l}2.49 \\
(6.0) \\
\end{array}$ & $\begin{array}{l}18.23 \\
(4.0) \\
\end{array}$ & 12.0 & 88.0 \\
\hline 5 & Food service & $\begin{array}{l}25.9 \\
(5.0)\end{array}$ & $\begin{array}{l}2.90 \\
(7.0)\end{array}$ & $\begin{array}{l}23.00 \\
(5.0)\end{array}$ & 11.2 & 88.8 \\
\hline 6 & Consumer Electronics & $\begin{array}{l}15.54 \\
(3.0)\end{array}$ & $\begin{array}{l}3.32 \\
(8.0)\end{array}$ & $\begin{array}{l}12.22 \\
(3.0)\end{array}$ & 21.4 & 78.7 \\
\hline 7 & Pharmacy & $\begin{array}{l}15.54 \\
(3.0)\end{array}$ & $\begin{array}{l}0.83 \\
(2.0) \\
\end{array}$ & $\begin{array}{l}14.71 \\
(3.0) \\
\end{array}$ & 5.3 & 94.7 \\
\hline 8 & $\begin{array}{l}\text { Others } \\
\text { Footwear }\end{array}$ & $\begin{array}{l}56.98 \\
(11.0)\end{array}$ & $\begin{array}{l}9.12 \\
(22.0) \\
(4.0) \\
\end{array}$ & $\begin{array}{l}47.86 \\
(10.0)\end{array}$ & 16.0 & 84.0 \\
\hline 9 & TOTAL & 518 & 41.46 & 476.54 & 8.0 & 92.0 \\
\hline
\end{tabular}

Note: Figures in parentheses show the percentage share in total.

Source: Author's compilation and calculations using information from (i) Deloitte (2013), "Indian Retail Market Opening more doors", January[13], (ii) ASA (2013). A Brief Report on Retail Sector in India, August[18], and (iii) Michael Page (2013), The Indian Retail Sector Report 2013[8]

\subsubsection{Total Retail Market}

As shown in Table 3 and4 (also in Fig.2 and Fig.3), in both the years (2007 \&2012), Food and Grocery is the biggest contributor in total retail .This segment contributed about 60 percent of total retail. The next two major contributors in 2007 are Clothing \& Footwear (9.30\%) and Non Institutional Health care (7.95\%). Sports goods, Entertainment, Equipment and Books segments together contributed the least (2.71 percent) followed by Beverages $(3.55 \%)$ and personal care $(4.23 \%)$ from the bottom end. Furniture, Furnishing, Appliance \& Services and Jewellery, Watches etc occupied $6.77 \%$ and $5.92 \%$ shares respectively in total retail in 2007 .

In 2012, after Food and Grocery (60\%), the next two segments at second and third place, as per their relative share in the retail market are Apparel (8\%) \& Mobile and telecom (6\%). Food service and Jewellery had $5 \%, 4 \%$ shares respectively in total retail market. Consumer Electronics and Pharmacy had equal share (3\%) in total retail market.

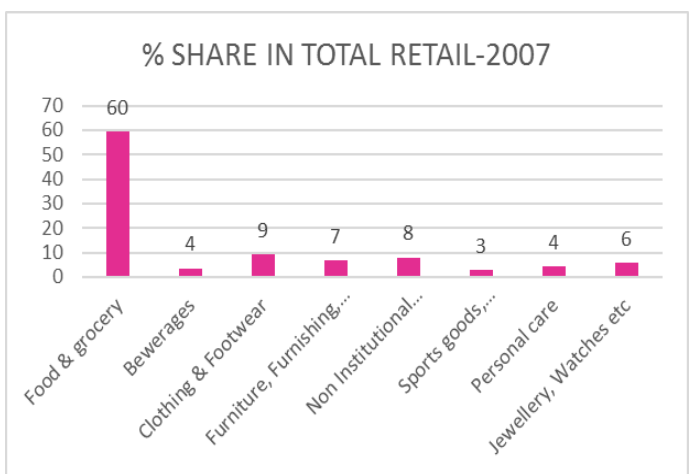

Figure 2

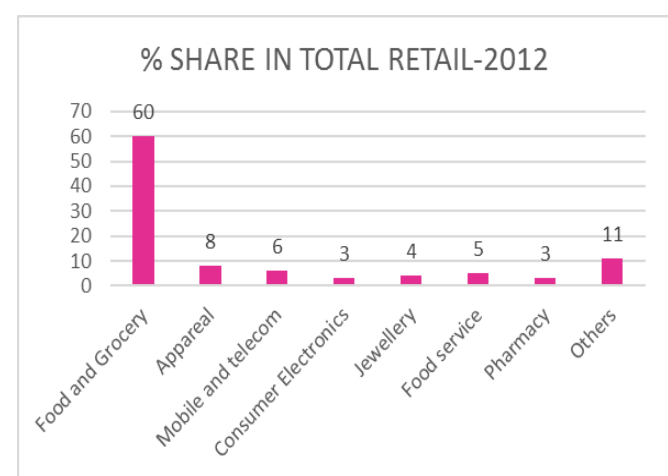

Figure 3

Source: Author's Compilation

\subsubsection{Organised Retail Market}

Fig. 4 and Fig.5 clearly indicates that Clothing/Apparel segment is the biggest contributor in organised retailing in India in both the years of study. In 2012 it alone accounted for 33 percent of organized retail followed by Food \& Grocery and Mobile and telecom with each having 11 percent share in organized retail. 


\subsubsection{Penetration of Organised Retail}

As revealed by Table 3, in the year 2007 penetration of organized retail in Food and Grocery segment was negligible $(0.7 \%)$ i.e. this segment was dominated by traditional retail. Organized retail had highest penetration in Clothing \& Footwear(18.51\%) followed by Sports goods, Entertainment, Equipment and Books(15.95\%) and Furniture, Furnishing, Appliance and Services(10.24\%).In Jewellery, Watches etc \& Personal care penetration of organized retail was $5.68 \%$ an $5.35 \%$ respectively.

In 2012, the Food and Grocery segment is dominated by traditional retail but organized retail penetration in this sector had more than doubled. It rose from a meager $0.7 \%$ in 2007 to $1.5 \%$ in 2012.In this year organized retail had highest penetration in Apparel (33.0\%) followed by Consumer Electronics $(21.4 \%)$ Mobile and Telecom (14.7\%), Jewellery (12\%) and Food service (11.20\%) segments.

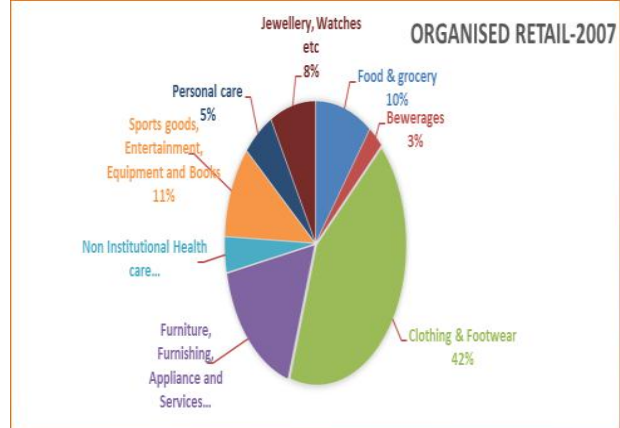

Figure 4

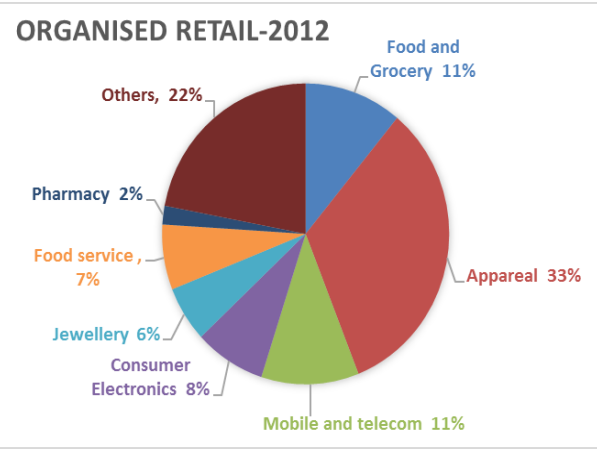

Figure 5

Source: Author's compilation

\section{Opportunities And Challenges Emerging In View Of Recent Policy Changes}

The proposal for permitting FDI in multi-brand retail trading, subject to specified conditions had been approved by Government of India on September 14, 2012. It is to note that in its meeting on 24.11.2011, the Cabinet had earlier approved the proposal but in order to evolve a broader consensus on the subject the implementation of the proposal was deferred. However, after having discussions with State Governments, representatives of consumer associations/organizations, micro \& small industry associations, farmers' associations and representatives of food processing industry and industry associations, it has finally been approved subject to the introduction of adequate safeguards [19]. Various sub-segments of the retail industry in India will be affected differently by The FDI policy conditions. One segment might have a low impact of a policy condition while at the same time it may be a major hurdle for another segment [13].

\subsection{Opportunities}

The Competitive environment created through new FDI policy norms offers a variety of opportunities to various stakeholders of Indian retail sector. Fig.6 aptly summarises the opportunities to various stakeholders.

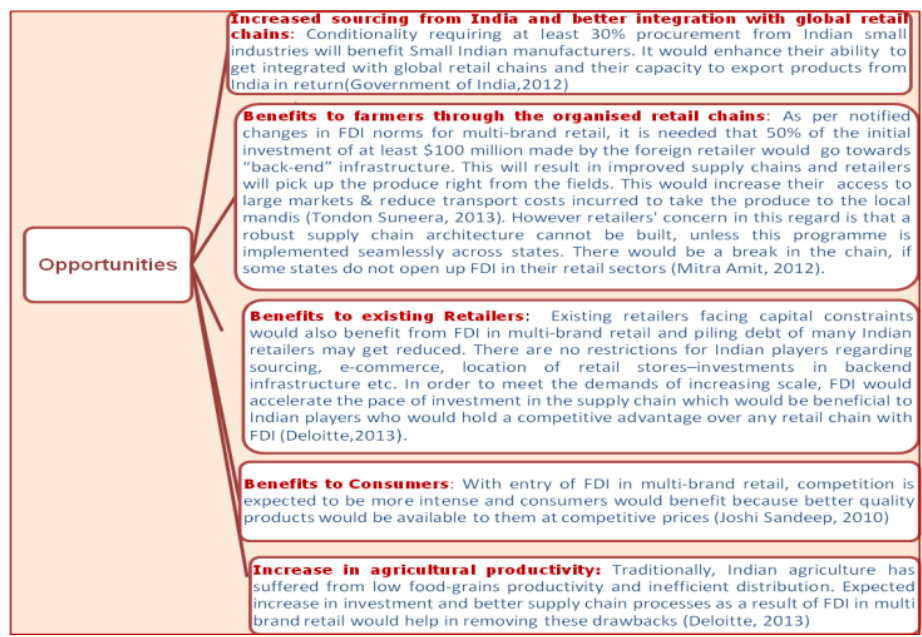

Figure 6: FDI in Multi Brand Retail - Opportunities

Source: Prepared by Author compiling information from (i) (Government of India (2012).Permitting FDI in multi-brand product retail trading[19] (ii) Deloitte (2013). Indian Retail Market Opening more doors[13], (iii) Mitra Amit (2012). FDI in multi-brand retail can strengthen supply chain links [20], (iv) Joshi Sandeep (2010). 
FDI in multi-brand retail would impact the unorganized sector[21] \& Tondon Suneera (2013). Govt notifies changes in FDI norms for multi-brand retail[22].

\subsection{Challenges}

The major challenges which Indian retail sector would face include shortage of skilled manpower, lack of industry status, Policy induced barriers, challenges resulting from Inappropriate planning and forecasting and financial risk due to high and substantial leverage etc. Fig. 7 presents a brief elaboration of these challenges.

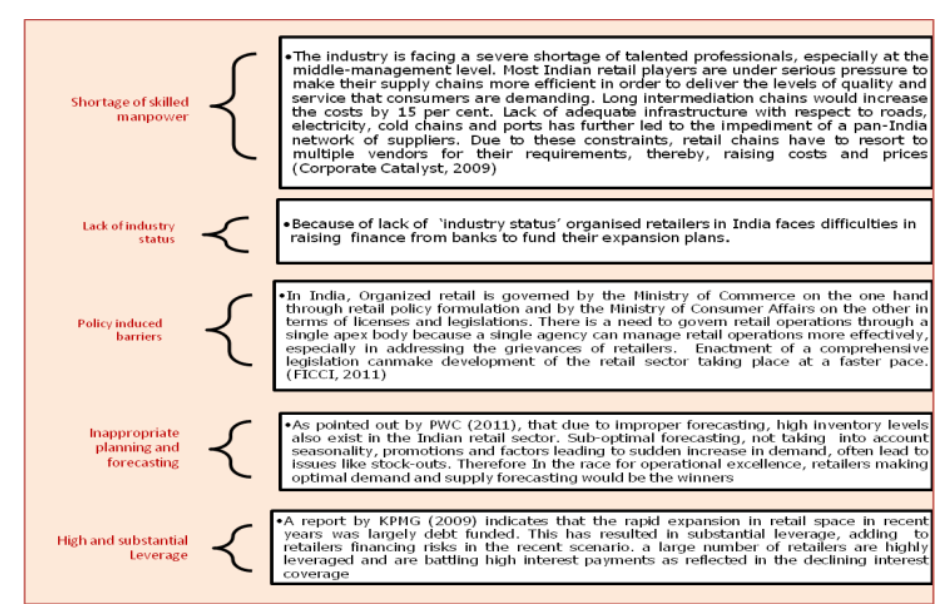

Figure 7: FDI in Multi Brand Retail-Challenges

Source: Prepared by Author compiling information from (i) FICCI (2011Sector Profile [7], (ii) PWC (2011) Winning in India's retail sector[14], (iii) KPMG (2009) Indian Retail: Time to change lanes[23]\& (iv) Corporate Catalyst (2009) Retail Industry in India[11].

\subsection{Solutions}

For the retailers to be able to successfully face the challenges emerging in new competitive environment due to Indian Government's policy of permitting FDI in multi-Brand retail, some of the key solutions as presented in Fig. 8 are:

- Mastering supply chain to drive competitive advantage

- Product Localisation

- Securing the right retail real estate

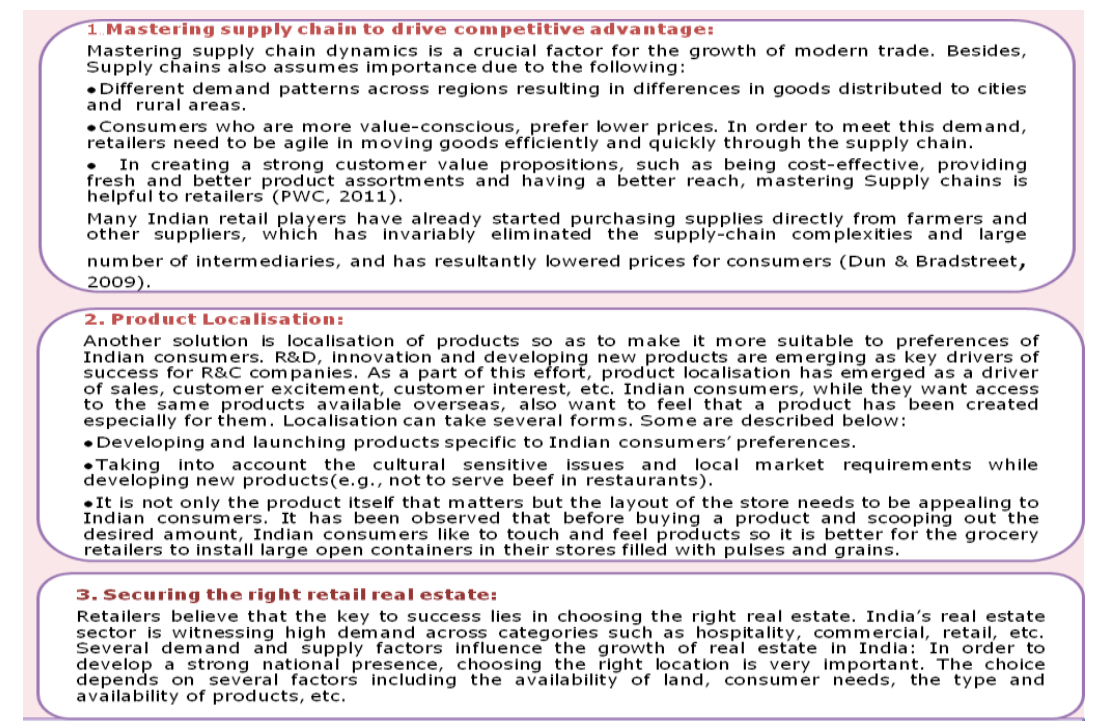

Figure 8: FDI in Multi Brand Retail - Solutions for Success

Source: Prepared by the Author using information from PricewaterhouseCoopers (PWC) 2011. Winning in India's retail sector [14] \& Dun \& Bradstreet (2009). Indian Retail Industry: Challenges, Opportunities and Outlook [1] 


\section{Conclusion}

The present study finds that The Indian retail sector is evolving rapidly. The size of India's retail industry is expected to more than double to $\$ 1.3$ trillion by 2020 . Further organised retail's penetration in India's total retail is on increase. Recent policy changes and greater external liberalisation of retail sector will bring many more foreign retailers to India. It is expected that FDI will accelerate the growth of organized retail. India's huge population with large proportion of young, increasingly brand- and fashion-conscious population, high potential growth in consumer expenditure, growing middle class are some of the factors due to which the macro trends for the sector looks favorable. Organized retail whose share in total retail was $8 \%$ in 2012 is expected to assume $24 \%$ share of total retail market in India in 2020. Among organized retail segments, Mass Grocery and Apparel are segments growing faster than other segments. In next few years, multi-brand organized retail is expected to expand in specialty stores such as Consumer Electronics, Footwear, Furniture and Furnishing etc. But the requirement of $30 \%$ procurement from Indian small industries may prove to be a major bottleneck for FDI in many of these segments. The global heads of retail chains keeping a mum on India in recently held World Retail Congress in Paris supports this viewpoint. While Mexico and the Philippines were being touted as the next big markets for commencing retail ventures, India's policies regarding sourcing and investments have put a question mark on prospective investments. Analyst say that if Walmart indeed pulls out of India, it may not have any impact on consumers as only eight per cent of the total retail is organised. But, confidence on India as a potential investment destination could be greatly marred [24]. However, recently Government of India has liberalised some FDI norms wef 22 August, 2013 to boost investors' sentiments.

In view of the recent policy changes, both the existing traditional retailers and modern organised domestic and foreign retailers would have opportunities and face challenges. On one hand, the policy is making the environment for the domestic retailers more and more competitive; it also intends to safeguard them through a variety of protective measures. Urban markets being highly competitive and saturated, it is expected that domestic retail players would divert towards small cities to tap the potential existing therein. Similarly, for international retailers to succeed in India, the choice of partner is very crucial. They should partner with such Indian retailers who will help them reach the end customers and who already possess lucrative front-end retail infrastructure. Thus, partnering with each other can prove mutually beneficial. An established domestic retailer will help foreign player bring in customers while the foreign player will benefit domestic retailer through its expertise in supply chain and logistics to further enhance the operational efficiency.

Lastly, the future prospects of Indian retail market are likely to have some macro-economic impact too. Expected positive impact of new policy on back-end infrastructure and better prospects of an efficient supply chain (linking farmers and small manufacturers directly with retailers) will minimise agricultural wastages (especially of fresh foods and vegetables). In agricultural sector, it can be expected that there will be higher use of technology in farming, packaging and storing. This would lead to a reduction in supply chain impediments, thereby, reducing supply side inflationary pressures. Another important macro-economic impact that is expected from expected expansion of modern retail is increasing opportunities of nonagricultural employment for rural youth and a better quality of living for the existing agricultural society. Once individuals become absorbed in retailer operations, they can access more equitable wages and benefits. These changes may make economic growth more inclusive. Further, modern participants in trade are tax-compliant and are large tax-payers. The organized retail sector would facilitates the generation of significant tax revenues through the building of a sophisticated supply chain. This impacts the logistics, transportation, warehousing, freight forwarding and other similar service sectors, all of which contribute to the exchequer through payment of indirect taxes, primarily the service tax.

However, to the above optimistic expectations, we also find fearful expressions that traditional retail may be competed out by organised retail in terms of prices, variety and quality. Modern retail offers a convenient shopping experience to consumers and is bound to affect kirana and small traders. Many experts including Mr Rangarajan hold the view that kirana stores will survive and can become part of modern retail by organising themselves and getting assimilated into the organised sector[25], Similarly, in the opinion of some other experts, in India, the so-called mom-and-pop retailer is a very savvy businessman, and has customer relationship management skills and service levels that are very hard to beat[26].Therefore there is no need for great celebration or for deep despair over FDI in retail. The nuances are still to be worked out.

\section{Scope for Future Research}

a. Further studies need to be carried out to make a comparative analysis of role and performance of Indian and foreign organized retailers so as to give some direction to future policy framing

b. Studies relating to retail sector may also be conducted at state level to find out the variations in performance of organized and unorganized retailers as well as Indian and foreign retailers across states. Such studies may also be useful in establishing fundamental causes of such variations. 


\section{References}

[1] Dun \& Bradstreet (2009). Indian Retail Industry: Challenges, Opportunities and Outlook. 26 August. Retrieved April 5, 2013 from www.dnb.co.in/IndianRetailIndustry/overview.asp

[2] Crown Stars (2013).Retail. Retrieved November 1, 2013, 2013 from crown stars.com/?page id=64

[3] Equitymaster (2012). Retailing Sector Analysis Report. 7 November. Retrieved March 23, 2013 from www.equitymaster.com > Research It

[4] Financial Express (2013). Retail sector can support existence of various formats.22 Feb. Retrieved March 26, 2013 from www.financialexpress.com/.../retail-sector-can-support-existence-of- $v$

[5] India Brand Equity Foundation (2013). Retail Industry in India. September. Retrieved November 7, 2013 from www.ibef.org/industry/retail-india.aspx

[6] A.T. Kearney (n.d.), Global Retailers: Cautiously Aggressive or Aggressively Cautious? 2013 Global Retail Development Index, Retrieved November 8, 2013 from https://www.atkearney.com/...retail/global-retail-development-index/full

[7] FICCI (2011). Sector Profile. 2 December. Retrieved April 5, 2013 from www.ficci.com/sector/33/ Project_docs/Sector-prof.pdf

[8] Michael Page (2013).The Indian Retail Sector Report 2013. Retrieved November 7, 2013 from www.michaelpage.co.in/websitepdf/IN_Retail_sector_report_2013.pdf

[9] Subhadip Mukherjee (2011): Policies of Retail Sector of India and Other Selected Countries. UTMS Journal of Economics 2 (2): 171-180. Retrieved April 5, 2013 from www.utms.cc/e-student/index.php?option=com_docman..

[10] Business Standard (2013). India Ratings maintains negative outlook for retail sector. January 15. Retrieved April 4, 2013 from www.business-standard.com/.../india-ratings-maintains-negative-outl

[11] Corporate Catalyst India (2009). Retail Industry in India. 24 June. Amazon Web Services. Retrieved April 9, 2013 from.pagalguy.s3.amazonaws.com/forum/files/.../indias_retail_sector.pdf

[12] Deloitte (2011). Indian Retail Market: Embracing a new trajectory. September. Retrieved March 29, 2013 from www.deloitte.com/assets/Dcom-India/.../Indian_Retail_Market.pdf

[13] Deloitte (2013). Indian Retail Market Opening more doors. January. Retrieved from www.deloitte.com/...India/../Indian_Retail_Report_Opening more_d...

[14] PricewaterhouseCoopers (2011). Winning in India's retail sector, Factors for success. Retrieved April 5, 2013 from list2.pwc.fr/assets/...retail.../pwc_winning_in_india_retail_sector_1.pdf

[15] ASA (2012). A Brief Report on Retail Sector in India, August, ASA and Associates chartered accountants. Retrieved April 2,2013 from www.asa.in/pdf/surveys_reports/Retail-Industry-in-India.pdf

[16] FICCI (n.d.). Retailing - Welcome to India in Business: Industry\& Services. Ministry of External Affairs, Government of India, ITP Division. Retrieved November 5, 2013 from www.indiainbusiness.nic.in/industry-infrastructure/...sectors/retailing.htm

[17] Girish K. Nair \& Harish K Nair (2011). FDI in India's Multi Brand Retail Sector: How to Get Ready for the Big Play. Munich, GRIN Publishing GmbH Retrieved April 9, 2013 from http://www.grin.com/en/e-book/183618/fdi-in-india-s-multi-brand-retailsector-how-to-get-ready-for-the-big

[18] ASA (2013). A Brief Report on Retail Sector in India, August, ASA and Associates chartered accountants. Retrieved November 7 , 2013 from www.asa.in/asa-knowledge-bank-surveys-reports.asp

[19] Government of India (2012).Permitting FDI in multi-brand product retail trading. Press Information Bureau, Government of India Retrieved April,5 2013 from pib.nic.in/newsite/erelease.aspx?relid=87767

[20] Mitra, Amit (2012). FDI in multi-brand retail can strengthen supply chain links.18 November. Retrieved March 27, 2013 from www.thehindubusinessline.com/.../fdi-in-multibrand-retail-can-streng

[21] Joshi Sandeep(2010). FDI in multi-brand retail would impact the unorganized sector. The Hindu, August 22. Retrieved August 5, 2013 from www.thehindu.com/.../tp.../fdi-in-multibrand...would.../article587583.ece

[22] Tondon Suneera (2013): Govt notifies changes in FDI norms for multi-brand retail, Live Mint and The Wall Street Journal,23 August Retrieved November 7, 2013 from www.livemint.com/.../Govt-notifies-changes-in-FDI-norms-for-...

[23] KPMG (2009). Indian Retail: Time to change lanes. Retrieved April 5, 2013 from www.kpmg.com/cn/ en/.../ pages/indian-retail-o200904.aspx

[24] Menon Bindu D. (2013).Multi-Brand Retail: Has India fallen off global players' radar? The Hindu Business Line. Retrieved November 7, 2013 from www.thehindubusinessline.com/.../multibrand-retail...india.../article5210

[25] The Hindu (2012). Organised retail out-competes Kirana.21 September. Hyderabad. Retrieved April 9, 2013 from www.thehindu.com > Business > Industry

[26] Bijapurkar Rama, R Sriram \& S Raghunandan (2012). Decoding the Detail in Retail. 26 October, Forbes India. Retrieved March 27, 2013 from infostreams.in/2012/10/26/decoding-the-detail-in-retail/ 